\title{
PERMASALAHAN PEMBAYARAN GANTI RUGI PENGADAAN TANAH BAGI PELAKSANAAN PEMBANGUNAN UNTUK KEPENTINGAN UMUM
}

\author{
Ujang Bahar ${ }^{1}$
}

\begin{abstract}
Abstrak
This paper discusses the issues related to land acquisition for the purpose of building public infrastructure. The land acquisition is carried out by the Ministry of government institution/Agency/Work Unit and funded by the National or Regional State Budget pursuant to the Presidential Regulation No. 36/2005 dtd. 3 May 2005 which is revised in Pressidential Regulation No. 65/2006. The common problem arising is the prolonged land-value related disagreement between the party employing the land acquisition and the local community or individuals in possession of the land ownership rights. Often are prices set by landowners far beyond the reasonable ceiling, while fund allocated for the land clearance is very limited. If after many consultations an agreement on price cannot be reached, the employer of the land acquisition will determine the form and amount of the compensation payment and delegate its disbursement to the District Court (Consignment) with jurisdiction covering the land is dispute. This consignment institution is not legally acknowledged and is contradictory to the state expenditure mechanism, which requires public expenditure to be made against legitimate documents and proofs for its proper as well as rightful usage. The disbursement mechanism of payment made available from the National State Budget, in particular the payment related to compensation of land acquisition for the purpose of public infrastructure project, requires it to be made directly to the bearer of the land ownership rights after the land has been declared as cleared. The receipt of consignment made to the Court cannot be considered as a legitimate proof or public expenditure.
\end{abstract}

${ }^{1}$ Penulis bekerja pada Dep.Keuangan RI, Jakarta, pernah sebagai Kepala Kantor Perbendaharaan dan Kas Negara (KPKN) di Watampone dan Merauke, Kepala Kantor Verikasi Pelaksanaan Anggaran, Ditjen Anggaran Dep. Keuangan Kendari, Kepala Bidang Akuntansi dan Pelaporan Kanwil Ditjen Perbendaharaan Dep. Keuangan juga di Kendari, Terakhir sebagai Kepala Bidang Pembinaan Perbendaharaan dan Kas Negara di Bandung. Sekarang sebagai Widyaiswara Dep. Keuangan, Aktif mengajar pada Sekolah Tinggi Akuntansi Negara Jakarta, dan Dosen Luar Biasa Fisip Unpad Bandung. Kandidat Doktor HTN Unpad. 
Kata kunci: tanah, masalah pengadaan tanah, ganti rugi, kepentingan umum, pembangunan

\section{Pendahuluan}

Diskusi tentang tanah sangat menarik dan tidak akan ada putusputusnya karena kita dihadapkan pada persoalan pertentangan kepentingan antara individu, masyarakat dan Negara. Tanah merupakan salah satu hak asasi manusia sebagaimana telah diakui oleh Konstitusi kita UUD 1945 melalui amandemen Pasal $28 \mathrm{H}$ ayat (4) yang lengkapnya berbunyi:

Setiap orang berhak mempunyai hak milik pribadi dan hak milik tersebut tidak boleh diambil alih secara sewenang-wenang oleh siapapun."

Tanah memiliki keterikatan dan keterkaitan yang sangat erat dengan individu pemiliknya. Dengan kelompok Pengelolanya. Tanah mempunyai hubungan filosifis, antropologis dan spiritual dengan kaum yang menguasainya. Bahkan tanah menjadi salah satu unsur atau syarat adanya negara (tanah air Indonesia). Prof. Djuhaendah Hasan mengatakan:

Sikap masyarakat Indonesia yang sangat menghargai tanah sebagai dasar kehidupan mereka terlihat dari penggunaan kata tanah dalam bahasa Indonesia yang mencerminkan sikap masyarakat Indonesia itu antara lain untuk menyebut Negara dengan kata tanah air, tanah tumpah darah, tanah pusaka, hal mana menunjukan betapa berartinya tanah dalam kehidupan masyarakat bangsa Indonesia. ${ }^{2}$

Demikian dekatnya keterikatan tersebut menyebabkan orang baik perorangan maupun kelompok (kaum) bisa berbuat nekat dan apa saja jika hak atas tanahnya diganggu olah pihak lainnya. Hubungan persaudaraan bisa sirna karena sengketa pertanahan. Jalinan kekerabatan dan persekutuan putus karena masalah pertanahan. Bahkan orang bisa saling "bunuh" hanya karena mempertahankan haknya atas tanah. Kita sering mendengar kasus pembunuhan antar sesama saudara karena memperebutkan tanah warisan.

2 Djuhaendah Hasan, Aspek Hukum Ekonomi dalam Pengadaan Tanah Untuk Kepentingan Pembangunan, Makalah pada Seminar Nasional Pengadaan Tanah Untuk Kepentingan Pembangunan, (Jakarta 14 September 2006), hal. 1. 
Tanah memiliki fungsi ganda sebagai social asset dan sebagai capital asset. Sebagai social asset tanah dikalangan masyarakat (masyarakat hukum adat) Indonesia merupakan sarana pengikat kesatuan sosial untuk hidup dan berkehidupan diatas tanah. Sebagai capital asset tanah merupakan faktor modal dalam pembangunan ekonomi. Oleh karena itu pengambilan keputusan dan kebijakan oleh Pemerintah berkaitan dengan tanah harus dilakukan secara hati-hati. Untuk kondisi sosial budaya dan hukum tanah pada masyarakat Indonesia yang beraneka ragam, kehati-hatian ini perlu dicermati untuk menjaga agar tidak menimbulkan disintegrasi pada $\mathrm{NKR}^{3}$. Dengan kata lain politik hukum di bidang pertanahan yang akan dijalankan atau di perankan oleh pemerintah haruslah politik hukum pertanahan yang berusaha menghindari terjadinya konflik dan sengketa antara kepentingan hukum dan kepentingan pembangunan, antara kepentingan hak asasi manusia dengan kepentingan umum, antara kepentingan pemerintah dan kepentingan rakyat banyak, antara kepentingan kesempatan kerja dengan kepentingan pertahanan dan keamanan, antara kepentingan ekonomi dan kepentingan memajukan kesejahteraan rakyat sebagaimana dimaksudkan dalam pembukaan UUD 1945.

Peran pemerintah tidak terbatas hanya bertanggungjawab terhadap pemeliharaan ketertiban dan ketentraman masyarakat semata, akan tetapi juga bertanggungjawab atas kesejahteraan masyarakat dan tidak satupun aspek kehidupan masyarakat yang lepas dari campur tangan pemerintah. Dengan demikian hubungan antara Negara dan hukum disatu sisi melahirkan keterikatan Negara pada hukum dan pada sisi lainnya melahirkan keterikatan hukum pada Negara. Peran hukum dalam pembangunan Negara diwujudkan secara nyata melalui dua aspek utama. R. Ibrahim mengatakan:

\begin{abstract}
Pada langkah awal hukum menata kehidupan Negara dan meletakan dasar yuridis bagi perencanaan pembangunan nasional, satu diantaranya adalah pembangunan ekonomi. Langkah selanjutnya adalah pembentukan hukum dan penerapannya. Hukum menciptakan kondisi-kondisi yang memungkinkan pelaksanaan pembangunan dan mengamankan hasil-hasilnya ${ }^{+}$
\end{abstract}

${ }^{3}$ Hermayulis, Aspek-Aspek Hukum Hak Pakai Atas Tanah Negara sebagai Objek Jaminan, "Hukum Bisnis volume 10", (Jakarta), hal. 49.

${ }^{4}$ R. Ibrahim, "Prospek Badan Hukum Milik Negara dan Kepentingan Umum", (Bandung: PT. Citra Aditya Bakti, 1997), hal. 10. 
Sebagai suatu Negara yang sedang mengalami perubahan atau yang sedang membangun menuju kesejahteraan guna mewujudkan cita-citanya maka Mochtar Kusumaatmadja mengatakan:

Peran hukum dalam pembangunan adalah menjamin bahwa perubahan itu terjadi dengan teratur. Baik perubahan maupun ketertiban merupakan tujuan kembar dari masyarakat yang sedang membangun, maka hukum menjadi alat yang tidak dapat diabaikan dalam proses pembangunan. Oleh karenanya hukum memegang peranan yang penting bagi sukses atau tidaknya pembangunan ${ }^{5}$.

Lebih jauh mengenai peran hukum tersebut dikatakan oleh Mochtar Kusumaatmadja:

Hukum merupakan sarana pembaruan masyarakat didasarkan atas anggapan bahwa adanya keteraturan atau ketertiban dalam usaha pembangunan atau pembaruan itu merupakan sesuatu yang diinginkan atau bahkan dipandang (mutlak) perlu. Anggapan lain yang terkandung dalam konsepsi hukum sebagai sarana pembangunan adalah bahwa hukum dalam arti kaidah atau peraturan hukum memang bisa berfungsi sebagai alat (pengatur) atau sarana pembangunan dalam arti penyalur arah kegiatan manusia kearah yang dikehendaki oleh pembangunan atau pembaruan. Kedua fungsi tersebut tadi diharapkan dapat dilakukan oleh hukum disamping fungsinya yang tradisional yakni menjamin adanya kepastian ketertiban".

Pembangunan sarana pendidikan, agama, infrastruktur atau pembangunan fisik lainnya tentu memerlukan lahan yang terkadang dilakukan dengan cara mengambil lahan milik penduduk, atau masyarakat adat (tanah ulayat). Dimasa lalu kebutuhan akan lahan tersebut sering dilakukan dengan cara pembebasan tanah dengan penggantian kerugian yang dirasakan tidak seimbang. Karena dalam praktek pembebasan lahan pada masa itu Pemerintah sering lebih mementingkan aspek hak menguasai tanah

5 Mochtar Kusumaatmadja, "Konsep-Konsep Hukum Dalam Pembangunan", (Bandung: Alumni, 2002), hal. 20.

${ }^{6}$ Ibid, hal. 88 . 
oleh Negara ${ }^{7}$, dan mengabaikan aspek kemakmuran rakyat. Pada hal sesuai dengan paham Negara kesejahteraan yang dianut Indonesia, pasal 33 ayt (3) UUD 1945 telah menentukan keseimbangan diantara keduanya. Oleh karenanya di era reformasi dan keterbukaan ini sering terjadi kasus individu atau masyarakat yang tanahnya pernah dibebaskan dengan alasan untuk kepentingan umum menggugat atau mempersoalkan kembali ganti rugi yang pernah diterimanya. Akibatnya pembangunan infrastruktur sering terhambat persoalan pembebasan lahan bahkan menggantung terutama apabila tidak ada kesepakatan tentang ganti rugi.

Menyadari akan hal ini maka pemerintah mengambil kebijakan mempercepat proses pengadaan tanah bagi pelaksanan pembangunan untuk kepentingan umum dengan tetap memperhatikan prinsip penghormatan terhadap hak-hak yang sah atas tanah tersebut dan bersikap transparan dengan mengeluarkan Perpres No.36 Tahun 2005 tanggal 3 Mei tahun 2005 Tentang Pengadaan Tanah bagi Pelaksanaan Pembangunan untuk Kepentingan Umum. Dalam Perpres ini disebutkan bahwa yang termasuk pembangunan untuk kepentingan umum yang dilaksanakan pemerintah atau pemerintah daerah adalah:

a. Jalan umum, jalan tol, rel kereta api (di atas tanah, di ruang atas tanah, ataupun diruang bawah tanah), saluran air minum/air bersih, saluran pembuangan air dan sanitasi;

b. Waduk, bendungan, bendung, irigasi dan bangunan pengairan lainnya;

c. Rumah sakit umum dan pusat kesehatan masyarakat;

d. Pelabuhan, Bandar udara, stasiun kereta api dan terminal;

e. Peribadatan

f. Pendidikan atau sekolah;

g. Pasar umum;

h. Fasilitas pemakaman umum;

i. Fasilitas keselamatan umum;

j. Pos dan telekomunikasi;

k. Sarana olah raga;

1. Stasiun penyiaran radio;

m. Kantor Pemerintah, Pemda, perwakilan Negara asing, Perserikatan Bangsa-Bangsa (PBB), dan atau lembaga-lembaga internasional dibawah naungan $\mathrm{PBB}$;

n. Fasilitas Tentara nasional Indonesia dan Kepolisian Negara Republik Indonesia sesuai dengan tugas pokok dan fungsinya;

${ }^{7}$ Djuhaendah Hasan, Op. Cit., hal. 1. 
o. Lembaga pemasyarakatan dan rumah tahanan;

p. Rumah susun sederhana;

q. Tempat pembuangan sampah;

r. Cagar alam dan cagar budaya;

s. Pertamanan;

t. Panti sosial;

u. Pembangkit, transmisi, distribusi tenaga listrik.

Pembatasan dan pengklasifikasian demikian menimbulkan protes, kritikan dan unjuk rasa dimana-mana ditengah masyarakat, karena menganggap ada kepentingan terselubung dibalik Perpres tersebut yang sesungguhnya bukan untuk kepentingan umum, tetapi untuk kepentingan sementara kelompok pengusaha tertentu. Disamping itu juga karena adanya kecurigaan dan trauma terhadap fungsi sospol TNI dan Polri.

Atas tekanan dan desakan masyarakat yang terus menerus dan agar Perpres tentang pengadaan tanah bagi pelaksanaan pembangunan untuk kepentingan umum ini lebih mencerminkan rasa keadilan masyarakat, maka pemerintah akhirnya mengambil keputusan melakukan perubahan dan penyempurnaan terhadap Perpres no. 36 Tahun 2005 dengan Perpres No. 65 Tahun 2006 Tangal 5 Juni 2006 Tentang Perubahan atas Peraturan Presiden Nomor 36 Tahun 2005 Tentang Pengadaan tanah bagi Pelaksanaan Pembangunan Untuk Kepentingan Umum. Dengan demikian Perpres Nomor 65 Tahun 2006 tidak mencabut Perpres No.36 tahun 2005, tetapi hanya menyempurnakannya saja.

Satu hal yang dihilangkan yang merupakan tuntutan masyarakat adalah tidak ada lagi pengadaan tanah bagi pelaksanaan pembangunan dengan alasan untuk kepentingan umum dengan cara pencabutan hak atas tanah. Karena memang pencabutan hak hanya bisa dilakukan dengan undangundang. Batasan pembangunan untuk kepentingan umum juga dipersempit, dengan tidak memasukkan lagi (menghilangkan) kepentingan umum yang terselubung kepentingan pihak tertentu didalamnya yaitu:

1. Rumah sakit umum dan kesehatan masyarakat;

2. Peribadatan;

3. Pendidikan atau sekolah;

4. Pasar umum;

5. Fasilitas pemakaman umum;

6. Fasilitas keselamatan umum;

7. Pos dan telekomunikasi;

8. Sarana olahraga;

9. Stasiun penyiaran radio, televisi dan sarana pendukungnya; 
10. Kantor pemerintah, pemerintah daerah, perwakilan Negara asing, Perserikatan Bangsa-Bangsa, dan atau lembaga-lembaga internasional dibawah naungan Perserikatan Bangsa-Bangsa;

11. Fasilitas Tentara Nasional Indonesia dan Kepolisian Negara Republik Indonesia sesuai dengan tugas pokok dan fungsinya;

12. Lembaga pemasyarakatan dan rumah tahanan;

13. Rumah susun sederhana;

14. Pertamanan; dan

15. Panti sosial.

Sehingga dengan demikian yang termasuk kategori pembangunan untuk kepentingan umum hanya tinggal:

1. Jalan umum dan jalan tol, rel kereta api (di atas tanah, di ruang atas tanah, ataupun di ruang bawah tanah), saluran air minum/air bersih, saluran pembuangan air dan sanitasi;

2. Waduk, bendungan, bendungan irigasi dan bangunan pengairan lainnya;

3. Pelabuhan, Bandar udara, stasiun kereta api, dan terminal;

4. Fasilitas keselamatan umum, seperti tanggul penanggulangan bahaya banjir, lahar dan lain-lain bencana;

5. Tempat pembuangan sampah;

6. Cagar alam dan cagar budaya; dan

7. Pembangkit, transmisi, distribusi tenaga listrik.

Tetapi satu aspek yang lebih menarik minat penulis untuk dikaji lebih mendalam dari kedua perpres tersebut adalah mengenai uang ganti rugi yang dititipkan ke pengadilan negeri (konsinyasi), jika tidak tercapai kesepakatan harga antara pemilik lahan dengan instansi pemerintah dan/atau pemerintah daerah yang memerlukan tanah, atau terjadi sengketa kepemilikan setelah penetapan ganti rugi.

Hal ini menarik karena bagaimanapun sumber pendanaan dari pengadaan tanah bagi pelaksanaan pembangunan untuk kepentingan umum tersebut adalah dari uang Negara. Atau dari Anggaran Pendapatan dan Belanja Negara/Daerah (APBN/D). Kita mengetahui mekanisme pengeluaran uang Negara atau Belanja Negara memiliki ketentuan dan pertanggungjawaban tersendiri. Oleh karena itu masalah yang ingin diurai dalam tulisan ini adalah:

1. Apakah Lembaga Titipan (Konsinyasi) tersebut memang diperlukan? 
2. Apakah Penitipan uang ganti rugi ke pengadilan itu tidak menyalahi ketentuan tentang pembayaran (pengeluaran Negara) dalam rangka pelaksanaan APBN?

\section{Mekanisme Pengadaan Tanah untuk Pembangunan}

\section{A. Hak Atas Tanah}

Sesuai dengan prinsip Negara hukum kesejahteraan atau negara hukum materil yang dianut Indonesia, maka negara wajib memberikan perlindungan terhadap hak yang dimiliki warganya. Tidak terkecuali hak dalam bidang pertanahan. Landasan hukumnya jelas yakni pasal 33 ayat (3) UUD 1945. yang menyatakan bahwa bumi, air, dan kekayaan alam yang terkandung didalamnya dikuasai oleh Negara dan dipergunakan untuk sebesar-besar kemakmuran rakyat. Walaupun dalam praktek pemerintahan sebelumnya pelaksanaan pasal tersebut lebih condong kepada aspek menguasai oleh Negara dan melupakan aspek kesejahteraan rakyat. Hak warga negara untuk memperoleh sesuatu hak atas tanah dijamin oleh UU, hak seseorang dilindungi dari gangguan pihak lain tanpa alas hak yang sah dalam segala bentuknya baik fisik maupun non fisik, demikian juga hak atas tanah seseorang tidak boleh dirampas dengan sewenang-wenang dan secara melawan hukum, termasuk oleh penguasa sendiri. Bahkan dengan keluarnya UU No. 39 Tahun 1999 sebagai penjabaran lebih lanjut dari Pasal 28 UUD. 1945, maka semakin bertambah jelas bahwa hak atas tanah merupakan hak asasi, yang pembatasan/pembebasan penguasaan atas hak tersebut hanya dapat dilakukan dengan UU.

UUPA Pasal 9 ayat (2) menyebutkan bahwa Tiap-tiap warga Negara Indonesia, baik laki-laki maupun wanita mempunyai kesempatan yang sama untuk memperoleh sesuatu hak atas tanah serta mendapat manfaat dari hasilnya, baik bagi diri sendiri maupun bagi keluarganya. Sekalipun dalam kenyataannya akses yang dijamin oleh UUPA tersebut dalam praktek ditentukan dua faktor lain yakni pemerintah dan sektor swasta "yang mempunyai posisi tawar menawar berbeda" sehingga boleh dikata makna pasal 9 UUPA tersebut belum memperoleh bentuk yang konkrit.

Dengan meningkatnya intensitas pembangunan yang menuntut penyediaan tanah yang relative luas untuk berbagai keperluan (Permukiman, industri, berbagai prasarana) memaksa alih fungsi tanah pertanian menjadi non pertanian dengan segala akibatnya. Dalam perkembangannya alih fungsi tersebut ikut menyentuh pola kehidupan 
petani yang semakin sulit untuk menghindarkan diri dari keterpaksaan melepaskan tanahnya yang karena alasan kepentingan pembangunan terpaksa mengalihkan fungsi tsb. ${ }^{8}$

Didalam UUPA selain dikenal beberapa hak atas tanah, seperti hak milik, hak guna usaha, hak guna bangunan, hak pakai dan hak sewa, maka diakui juga keberadaan hak adat, yang disebut dengan hak ulayat. Sebetulnya UUPA sendiri tidak memberikan penjelasan tentang hak ulayat itu, kecuali menyebutkan bahwa yang dimaksud dengan hak ulayat adalah Beschikkingrecht. Pengertian beschikking recht pertamatama dikemukakan oleh Mr. C.C.J. Maassen dan A.P.G. Hens dalam bukunya Agrarische Regeling voor het Gouvernementsgebied van java en madura (Peraturan agraris di daerah gubernemen jawa dan madura) Jilid I Halam 5, yang menerangkan tentang hak ulayat:

Yang dinamakan hak ulayat (beschikkingrecht) adalah hak desa menurut adat dan kemauannya untuk menguasai tanah dalam lingkungan daerahnya buat kepentingan anggotaanggotanya atau kepentingan orang lain (orang asing) dengan membayar kerugian kepada desa, dalam hal mana desa itu sedikit banyak turut campur dengan pembukaan tanah itu dan turut bertanggungjawab terhadap perkaraperkara yang terjadi disitu yang belum dapat diselesaikan?.

Hak ulayat hanya dipergunakan sebagai istilah teknis yuridis yaitu adalah hak yang melekat sebagai kompetensi khas pada masyarakat hukum adat, berupa wewenang/kekuasaan mengurus dan mengatur tanah seisinya dengan daya laku kedalam maupun keluar (Laporan penelitian Integrasi Hak Ulayat Kedalam Yurisdiksi UUPA, DepdagriFH UGM tahun 1978).${ }^{10}$ Setiap daerah atau masyarakat hukum adat di Indonesia mempunyai hak ulayat. Didaerah Jambi dikenal dengan nama hak penghulu (ulayat kampong), tanah hak batin (ulayat marga/batin-yaitu kumpulan dari kampong-kampong yang dikepalai

8 Maria S.W. Sumardjono, "Kebijakan Pertanahan, antara Regulasi dan Implementasi”, (Jakarta: Penerbit Buku Kompas, 2004), hal. 29.

9 C.C.J. Maassen dan A.P.G. Hens, "Agrarische Regeling voor het Gouvernementsgebied van Java en Madura", Jilid 1, hal. 5, dikutip dari Eddy Ruchiyat, "Politik Pertanahan sampai Ord̦e Reformasi", (Bandung: Alumni, 2004), hal. 32.

${ }^{10}$ Maria S.W. Sumardjono, Op. Cit., hal. 85. 
seorang pesirah) dan tanah hak rajo. ${ }^{11}$ Djuhaendah Hasan memberikan batasan hak ulayat adalah:

Hak warga persekutuan hukum masyarakat adat atas tanah (air dan udara) beserta segala isinya diwilayah ulayat, yang berlaku baik ke dalam maupun ke luar. Berlaku ke dalam dalam hubungan pengaturan hak sesama warga ulayat, sedangkan ke luar yaitu mengatur dalam hubungan dengan warga luar ulayat dengan memberikan hak pada warga luar ulayat untuk dapat mengerjakan tanah untuk waktu tertentu dengan ijin kepala persekutuan setelah membayar uang pengakuan, uang pemasukan, mesi dan uang penggantian. ${ }^{12}$

Hak ulayat berada ditangan desa (gemeenschap) sebagai persekutuan dari orang-orang penduduknya. Persekutuan inilah yang mengatur sampai dimana hak-hak perseorangan akan dibatasi untuk kepentingan persekutuan itu. Tanda yang terpenting dari hak ulayat itu ialah bahwa ada perhubungan yang erat diantara hak persekutuan dengan hak perseorangan. Jika seorang dari penduduk membikin erat perhubungannya dengan sebidang tanah, tanah itu akan semakin berkurang, sebagaimana dapat kita lihat dalam perhubungan seorang desa dengan sawahnya, kebun, kolam (empang ikan) dan pekarangannya. Sebaliknya jika orang yang mempunyai tanah membikin perhubungannya dengan tanah itu kurang erat lagi, misalnya bertahun-tahun tidak mengerjakan atau memakai tanah itu, meninggalkan desa kediamannya dan sebagainya, maka hak desa akan lebih kuat lagi atau akan hidup lagi seperti semula. Jadi apabila hak perseorangan bertambah kuat, hak desa akan menjadi kurang kuat, begitu sebaliknya, jika hak perseorangan kurang kuat, hak desa akan menjadi tambah kuat. Dengan demikian dapat disimpulkan bahwa hak ulayat adalah hak bersama suatu kaum, suatu marga, atau suatu desa, atau hak komunal.

Yang menjadi objek pengadaan tanah bagi pelaksanaan pembangunan untuk kepentingan umum dengan cara pelepasan hak atau penyerahan hak atas tanah adalah kedua hak atas tanah tersebut (hak atas tanah menurut UUPA khususnya hak milik, dan hak ulayat) 1978), hal. 10.

1 A.P. Parlindungan, "Berbagai Aspek Pelaksanaan UUPA", (Bandung: Alumni,

${ }^{12}$ Djuhaendah Hasan, Op. Cit., hal. 7. 
yakni tanah-tanah yang berada di area atau wilayah pembangunan infrastruktur yang lokasinya secara tata ruang telah ditentukan oleh instansi pemereintah/pemerintah daerah yang membutuhkan dan tidak bisa dipindahkan ke lokasi lain.

\section{B. Masalah Pengadaan Tanah.}

Dalam masalah pengadaan tanah bagi pembangunan untuk kepentingan umum, maka isu sentral yang selalu menjadi topik hangat diskusi adalah batasan atau pengertian kepentingan umum itu sendiri. Kepentingan umum sebagai konsep tidak sulit dipahami tetapi tidak mudah untuk didefenisikan. Sering pengertian untuk kepentingan umum ditafsirkan sesuai dengan kepentingan kelompoknya atau golongannya. Dalam Keppres No. 55 Tahun 1993 maupun Perpres No. 36 Tahun 2005 (Perpres No. 65 tahun 2006), kepentingan umum didefenisikan sebagai kepentingan seluruh lapisan masyarakat. Sedang mengenai pembangunan untuk kepentingan umum dibatasi pada kegiatan pembangunan yang dilaksanakan oleh Pemerintah/Pemda yang selanjutnya dimiliki atau akan dimiliki oleh Pemerintah/Pemda. Pembangunan untuk kepentingan umum diformulakan dengan cara penyebutan (normative) apa-apa yang termasuk kepentingan umum dalam suatu daftar yang terdiri dari beberapa kegiatan seperti dikemukakan diatas. (Pada Perpres 36 Tahun 2005 sebanyak 21 kegiatan, pada perpres no. 65 Tahun 2006 tinggal 7 kegiatan). Dengan demikian pembebasan tanah yang dilakukan oleh Pemerintah/Pemda dengan cara pelepasan atau penyerahan hak, hanya terbatas untuk tujuh kegiatan tersebut.

Pemaknaan kepentingan umum kelihatannya mengikuti orientasi kebijakan pemerintah. Ketika orientasinya lebih terfokus pada pertumbuhan ekonomi, maka kepentingan umum cenderung didefenisikan secara luas. Sebaliknya bila pertumbuhan ekonomi tidak menjadi fokus, kepentingan umum cenderung didefenisikan secara sempit ${ }^{13}$.

Sebagaimana telah dikemukakan diatas bahwa hak atas tanah merupakan hak dasar (asasi) manusia, maka dalam pelepasan maupun penyerahannya haruslah mengakomodir prinsi-prinsip penghargaan terhadap hak-hak dasar manusia antara lain hak untuk sejahtera dan hidup layak. Kenyataannya dalam praktik yang terjadi selama ini, kesejahteraan sosial ekonomi masyarakat yang tanahnya diperlukan

\footnotetext{
${ }^{13}$ Maria S.W. Sumardjono, Op. Cit., hal. 107.
} 
untuk kegiatan pembangunan pasca pengadaan tanah tidak memperoleh perhatian. Tidak jarang terjadi pasca pelepasan hak, dengan telah diterimanya ganti rugi dan telah diserahkannya hak atas tanah kepada pihak yang memerlukan kehidupan sosial masyarakat menjadi menurun. Apalagi umumnya yang terkena dampak pelepasan hak atas tanah tsb adalah masyarakat golongan bawah dengan tingkat pendidikan minimum dan tinggal di pedesaan. Pemerintah lepas tangan. Mereka seolah dibiarkan mencari solusinya sendiri.

Untuk masa yang akan datang kiranya hal ini perlu mendapat perhatian dan tidak perlu terulang lagi antara lain dengan memberi kesempatan kepada masyarakat yang terkena dampak pembebasan tanah tersebut sebagai pegwai/pekerja pada proyek pemnbangunan infrastruktur yang bersangkutan, atau diberi kesempatan berusaha dalam bidang yang menunjang keberhasilan proyek. Misal sebagai supplier dsbnya.

Masalah lain yang perlu mendapat perhatian adalah masalah transparansi, keterbukaan dan keikut sertaan masyarakat dalam menyususn rencana tata ruang. Dengan mengetahui rencana tata ruang suatu wilayah, disatu sisi akan dapat meminimalisasi praktik percaloan, spekulasi dan bentuk praktik tak terpuji lainnya seperti kolusi dan korupsi. Sedang disisi lain akan dapat meningkatkan kesejahteraan mayarakat yang akan terkena dampak pembebasan tanah karena dari awal mereka telah mengetahui tingkat harga tanah didaerah tersebut. Dengan kata lain jika harga tanah menjadi tinggi keuntungannya akan dinikmati secara langsung. Tidak dinikmati spekulan-spekulan dan para calo tanah. Sehingga dari awal mereka sudah bisa mengantisipasi dan mempersiapkan diri terhadap ekses yang akan timbul dan menatap masa depan yang lebih pasti.

UU No. 24 Tahun 1992 Pasal 4 ayat-(2) Tentang Penataan Ruang menyebutkan, Setiap orang berhak untuk:

a. Mengetahui rencana tata ruang;

b. Berperan serta dalam penyusunan rencana tata ruang, pemanfaatan ruang, dan pengendalian pemanfaatan ruang;

c. Memperoleh penggantian yang layak atas kondisi yang dialaminya sebagai akibat pelaksanaan kegiatan pembangunan yang sesuai dengan rencana tata ruang.

Selama ini masalah keterbukaan informasi dan kejelasan tata ruang ini selalu terabaikan. Akibatnya dalam setiap usaha pembebasan tanah bagi pembangunan untuk kepentingan umum (proyek-proyek Pembangunan infrastruktur) pemerintah maupun pemerintah daerah 
selalu tidak berjalan mulus, bahkan terkadang mengalami kegagalan. Inti permasalahannya pada umumnya terletak pada tidak tercapainya kesesuaian harga antara yang ditawarkan oleh pemerintah/pemerintah daerah yang akan menggunakan tanah tersebut dengan pihak pemilik lahan, karena sesungguhnya yang bermain adalah para spekulan dan calo-calo tanah.

Masalah lain yang tidak kalah pentingnya yang perlu mendapat perhatian dalam persoalan pembebasan tanah ini adalah kegiatan melakukan survey dasar dan survey sosial ekonomi, sebagai kegiatan awal pengadaan tanah sebelum ditetapkan pemilihan lokasi pembangunan yang defenitif dan dimaksudkan untuk memperoleh informasi awal tentang masyarakat berikut asset yang akan terkena dampak. $^{14}$ Hasil survey tersebut dapat dijadikan dasar untuk mengambil kebijakan terhadap masyarakat yang akan terkena dampak. Seperti, kebijakan rencana pemulihan pendapatan, kebijakan pemulihan dampak fsikologis dan kultural, kebijakan relokasi pemukiman, dsbnya.

\section{Pengadaan Tanah oleh Pemerintah}

Pengadaan tanah oleh pemerintah bagi pelaksanaan pembangunan untuk kepentingan umum dilaksanakan dengan cara pelepasan atau penyerahan hak atas tanah. Diluar itu hanya boleh dilakukan dengan cara jual beli, tukar menukar, atau cara lain yang disepakati kedua belah pihak. Dengan demikian Perpres Nomor 36 tahun 2005 yang telah dirubah dan disempurnakan dengan Perpres Nomor 65 tahun 2006 tentang Pengadaan Tanah Bagi Pelaksanaan Pembangunan Untuk Kepentingan Umum hanya berlaku bagi pembangunan untuk kepentingan umum yang dilaksanakan oleh pemerintah atau pemerintah daerah yang selanjutnya dimiliki atau akan dimiliki oleh pemerintah atau pemerintah daerah.

Pengadaan tanah dilakukan secara langsung atas dasar musyawarah. Yang dimaksud dengan musyawarah adalah kegiatan yang mengandung proses saling mendengar, saling memberi dan saling menerima pendapat, serta keinginan untuk mencapai kesepakatan mengenai bentuk dan besarnya ganti rugi dan masalah

${ }^{14}$ Maria S.W. Sumardjono, Penerapan Prinsip Penghormatan Terhadap Hak Atas Tanah Dalam Pengadaan tanah Untuk kepentingan Pembangunan, Makalah pada Seminar Nasional Pengadaan Tanah Untuk Kepentingan Pembanguna, (Jakarta : 14 September 2006), hal. 5 . 
lain yang berkaitan dengan kegiatan pengadaan tanah atas dasar kesukarelaan dan kesetaraan antara pihak yang mempunyai tanah, bangunan, tanaman, dan benda-beda lain yang berkaitan dengan tanah dengan pihak yang memerlukan tanah (Pasal 1 ayat 10). Musyawarah dilakukan antara Panitia Pengadaan tanah mewakili pihak yang memerlukan lahan dan pemilik atau pemegang hak atas tanah yang akan dilepaskan. Dalam musyawarah kedua belah pihak harus mempunyai kedudukan yang setara. Bila jumlah pemegang hak atas tanah lebih banyak dan tidak memungkinkan musyawarah berjalan secara efektif, atau tanah yang akan dikenakan pelepasan hak merupakan tanah ulayat maka dibuka kemungkinan adanya wakilwakil yang ditunjuk diantara pemegang hak atas tanah, yang sekaligus bertindak sebagai wakil mereka (Pasal 10 ayat 2).

Penunjukan wakil tersebut harus dilakukan secara tertulis diatas kertas yang bermeterai cukup yang diketahui oleh Kepala Desa/Lurah atau surat penunjukan atau kuasa yang dibuat dihadapan pejabat yang berwenang. Agar musyawarah berjalan efektif, harus ada jaminan bahwa masyarakat pemegang hak atau wakilnya adalah orang-orang atau wakilnya yang benar-benar berhak atas tanah yang terkena dampak (bukan calo). Disamping itu harus ada jaminan bahwa musyawarah berjalan dalam suasana kondunsif tanpa ada tekanan sehingga benar-benar terjadi dialog antara pemegang hak atas tanah yang terkena dampak dan pihak yang memerlukan tanah. Hal yang dimusyawarahkan terutama adalah mengenai besarnya ganti kerugian. Ganti kerugian disini tidak hanya kerugian yang bersifat fisik seperti kehilangan tempat tinggal, bangunan, tanaman, dan benda-benda lain yang terkait dengan tanah, tetapi juga ganti kerugian terhadap kerugian yang bersifat non fisik seperti hilangnya kesempatan berusaha, pekerjaan, sumber penghasilan dan sumber pendapatan yang lain.

Berkaitan dengan itu maka keberadaan lembaga penilai harta tanah periu diperjelas tentang kualifikasi dan persyaratan pejabat penilai tersebut. Hal ini diperlukan untuk menjamin profesionalisme dan independensi lembaga tersebut dan tiadanya unsur KKN. Keberadaan suatu lembaga/tim yang bertugas untuk membuat suatu penilaian tentang harga tanah sangat penting karena hasil penilaiannya akan menjadi dasar untuk melakukan musyawarah dengan masyarakat. Untuk ganti kerugian yang bersifat fisik, apapun dasar penilaiannya (NJOP atau nilai nyata), lokasi dan letak tanah, luas tanah, peruntukan, sarana dan prasarana yang ada, dan faktor-faktor lain yang dapat berpengaruh terhadap harga tanah, hendaknya hasil akhir penilaian dapat dimanfaatkan oleh masyarakat untuk memperoleh penggantian 
yang setara dengan hak nya yang telah dilepaskan. Sedang ganti kerugian yang bersifat non fisik dalam bentuk yang dapat membantu masyarakat untuk memulihkan pendapatan dan kepercayaan dirinya (penyediaan lahan usaha pengganti, pelatihan untuk alih lapangan kerja, penyediaan lapangan kerja, skema kredit, dan lain-lain). Selanjutnya perlu juga dipikirkan kembali tentang bentuk ganti kerugian terhadap tanah ulayat. Bentuk ganti kerugiannya dengan kesepakatan masyarakat yang bersangkutan, dapat berupa penggantian untuk tanah kepunyaan bersama, bangunan, akses ke sumber daya alam untuk kehidupan sehari-hari. Sedang untuk ganti kerugian yang bersifat non fisik dapat berupa pemberian dana abadi. Musyawarah dalam menetapkan ganti rugi dipimpin oleh Ketua panitia pengadaan tanah. Dalam hal pembangunan untuk kepentingan umum yang tidak dapat dialihkan atau dipindahkan, secara teknis tata ruang ke tempat atau lokasi lain maka musyawarah dilakukan dalam jangka waktu 120 hari kalender terhitung sejak tanggal undangan pertama.

Apabila dalam musyawarah telah dicapai kesepakatan antara pemegang hak atas tanah dan instansi pemerintah dan/atau pemerintah daerah yang memerlukan tanah, panitia pengadaan tanah mengeluarkan keputusan mengenai bentuk dan besarnya ganti rugi sesuai dengan kesepakatan tersebut. Tetapi apabila setelah diadakan musyawarah berkali-kali namun belum juga dicapai kesepakatan maka panitia pengadaan tanah menetapkan bentuk dan besarnya ganti rugi dan menitipkan ganti rugi uang kepada Pengadilan negeri (Konsinyasi) yang wilayah hukumnya meliputi lokasi tanah yang bersangkutan. Tetapi pemegang hak atas tanah yang tidak dapat menerima keputusan tersebut dapat mengajukan keberatan kepada Bupati/Walikota atau Gubernur. Atau Menteri Dalam Negeri sesuai dengan kewenangan disertai dengan penjelasan dan sebab-sebab alasan keberatan tersebut. Selanjutnya Bupati/walikota atau Gubernur atau Menteri Dalam Negeri sesuai dengan kewenangannya mengupayakan penyelesaian mengenai bentuk dan besarnya ganti rugi tersebut dengan mempertimbangkan pendapat dan keinginan dari pemegang hak atas tanah atau kuasanya. Untuk kemudian mengambil keputusan yang dapat berupa pengukuhan atau mengubah keputusan Panitia Pengadaan Tanah mengenai bentuk dan/atau besarnya ganti rugi yang akan diberikan. Jika Keputusan Bupati/Walikota dau Gubernur atau Meneteri Dalam Negeri ini masih tidak dapat diterima oleh pemegang hak atas tanah dan lokasi pembangunan yang bersangkutan tidak bisa dipindahkan maka Bupati/Walikota atau Gubernur atau Menteri Dalam Negeri sesuai dengan wewenangnya 
mengambil tindakan mengusulkan penyelesaian dengan cara pencabutan hak atas tanah berdasarkan Undang-Undang Nomor 20 tahun 1961 tentang Pencabutan hak atas Tanah dan Benda-Benda yang ada diatasnya kepada Badan Pertanahan nasional dengan tembusan kepada Menteri dari instansi yang memerlukan tanah dan Menteri Hukum dan Hak Asasi Manusia. Untuk seterusnya Kepala Badan Pertanahan Nasional menyampaikan usul pencabutan hak atas Tanah tersebut kepada Presiden setelah berkonsultasi dengan Menteri yang memerlukan tanah dan Menteri Hukum dan Hak Asasi Manusia.

Terhadap Keppres tentang Pencabutan Hak Atas tanah atau Benda-Benda yang ada diatasnya tidak dapat diterima oleh pemegang hak atas tanah karena jumlah ganti rugi yang kurang layak misalnya, maka ia dapat meminta banding kepada Pengadilan Tinggi agar menetapkan ganti rugi sesuai dengan UU No. 20 tahun 1961 dan PP No. 39 Tahun 1973 tentang Acara Penetapan ganti Kerugian oleh Pengadilan Tinggi sehubungan Pencabutan hak-hak atas Tanah dan Benda-Benda yang ada diatasnya.

Sebetulnya untuk menghindari kesulitan mendapatkan lahan untuk pembangunan dan untuk menghindari permasalahan yang rumit karena pemegang hak atas tanah tidak mau melepaskan tanahnya atau setelah diadakan musyawarah berulang kali namun tidak juga dicapai kesepakan harga ganti rugi, kiranya asas pemisahan horizontal dapat dipertimbangkan. Tentunya dengan syarat harus jelas benar siapa sesungguhnya pemilik sah /pemegang hak sah dan ahli warisnya yang berhak dikemudian hari atas tanah yang dipergunakan oleh instansi Pemerintah/Pemda dengan hak sewa atas tanah yang diperlukan untuk pembangunan itu. Sebab jika tidak maka penerapan asas pemisahan horizontal ini tidak menyelesaikan permasalahan secara konprehensif tetapi hanya menundanya untuk sementara waktu. Mengingat penggunaan tanah untuk kepentingan pembangunan dalam jangka waktu sangat lama sementara pemilik/pemegang hak tersebut memiliki usia yang terbatas.

\section{Pembayaran Ganti Rugi atas Pengadaan Tanah}

Terdapat dua kemungkinan terhadap hasil musyawarah pembayaran ganti rugi antara pihak yang memegang hak atas tanah dengan yang memerlukan tanah:

1. Hasil musyawarah mencapai kesepakatan maka dilakukan pembayaran secara langsung kepada yang berhak (Pasal 11). 
2. Tidak tercapai kesepakatan maka uang ganti rugi dititipkan ke Pengadilan Negeri dalam wilayah hukum lokasi tanah tersebut (Pasal 10 ayat 2). Dengan alur pikir demikian berarti uang yang dipergunakan untuk pembayaran ganti rugi telah keluar dari kas Negara ${ }^{15}$, atau telah berada ditangan panitia pengadaan tanah atau instansi yang memerlukan tanah tetapi dititipkan di pengadilan. Yang menjadi pertanyaan apakah benar demikian ? mengingat mekanisme pengeluaran anggaran belanja Negara ( penggunaan uang Negara) mempunyai aturan ketentuan tersendiri. Untuk itu penulis ingin menguraikan lebih jauh mengenai mekanisme pengeluaran belanja Negara melalui APBN tersebut.

Pada masa Pemerintahan orde Baru APBN yang dijalankan pemerintah terkenal dengan sebutan anggaran yang berimbang dan dinamis. Dimana sisi penerimaan sama dengan sisi pengeluaran dan tiap tahunnya meningkat dari segi kuantitas. Tetapi sesungguhnya anggaran yang dijalankan tersebut adalah anggaran defisit, karena pengeluaran lebih besar dari penerimaan. Dan kekurangannya ditutup melalui pinjaman luar negeri. Baru setelah era reformasi Pemerintah secara terang-terangkan menyebutkan bahwa sistem anggaran yang kita anut adalah anggaran defisit. Dimana kekurangannya ditutup melalui Privatisasi BUMN, Penerbitan Obligasi Negara, dan Pinjaman Luar Negeri. Dengan demikian jelas bahwa pinjaman merupakan salah satu sumber pembiayaan defisit untuk menutup pembiayaan pembangunan. Anggaran negara sesungguhnya memegang peranan dan fungsi yang sangat penting bagi kelangsungan hidup negara. Oleh karena itu ia ditetapkan dengan UU. Bahkan UU nya bersifat khusus karena hanya berlaku untuk satu tahun anggaran.

Sebagaimana dimaksud pasal 23 ayat 1 UUD 1945 APBN sebagai wujud dari pengelolaan keuangan negara ditetapkan setiap tahun dengan UU dan dilaksanakan secara terbuka dan bertanggung jawab untuk sebesarbesarnya kemakmuran rakyat. Berbeda dengan UU yang lain yang masa berlakunya lebih dari satu tahun bahkan sangat panjang bisa puluhan tahun. Ketentuan pasal 23 ayat (1) ini memuat hak begrooting DPR. Cara menetapkan Anggaran Pendapatan Dan Belanja adalah merupakan suatu ukuran bagi sifat Pemerintahan Negara. Dalam negara yang berdasar fasisme anggaran ditetapkan semata-mata oleh Pemerintah. Akan tetapi dalam negara

${ }^{15}$ Perlu dipahami bahwa Pengadaan tanah bagi pelaksanaan Pembangunan untuk kepentingan umum dilakukan oleh Instansi atau Satuan Kerja Pemerintah atau Pemerintah Daerah, tentu sumber pendanaannya dari APBN/D. 
yang berdasarkan demokrasi atau kedaulatan rakyat anggaran pendapatan dan belanja itu ditetapkan dengan UU artinya dengan persetujuan DPR ${ }^{16}$.

Dalam mekanisme pengelolaan keuangan Negara (Belanja Negara) terdapat dua pihak yakni Menteri/Pimpinan Lembaga atau Kuasanya (Kepala Kantor/Unit Kerja disebut Kuasa Pengguna Anggaran/KPA) selaku pengguna anggaran yang bertanggungjawab atas pengelolaan anggaran pada Kementerian Negara/Lembaga yang bersangkutan dan Menteri Keuangan atau kuasanya selaku Bendahara Umum Negara (BUN). Menteri/Pimpinan lembaga berwenang menunjuk dan menetapkan para pejabat yang bertugas melakukan pengujian dan perintah pembayaran yang mengakibatkan pengeluaran Negara. Sedang Menteri Keuangan berwenang menunjuk pejabat kuasa BUN dan melakukan pembayaran berdasarkan permintaan pejabat pengguna anggaran atas beban rekening Kas Umum Negara. Kuasa Benadahara Umum Negara adalah Kantor Pelayanan Perbendaharaan Negara (KPPN). Sedang dokumen sumber yang dijadikan dasar pengeluaran Negara tersebut adalah DIPA atau dokumen lain yang dipersamakan dengan DIPA. Secara lengkap yang dimaksud dengan DIPA atau dokumen lain yang dipersamakan adalah dokumen pelaksanaan anggaran yang dibuat oleh Menteri/Pimpinan Lembaga atau satuan kerja (satker) serta disahkan oleh Direktur Jenderal Perbendaharaan atau Kepala Kantor Wilayah Direktorat Jenderal Perbendaharaan atas nama Menteri Keuangan dan berfungsi sebagai dasar untuk melakukan tindakan yang mengakibatkan pengeluaran Negara dan pencairan dana atas beban APBN serta dokumen pendukung kegiatan akuntansi pemerintah. ${ }^{17}$

Pembayaran atau pengeluaran Belanja Negara oleh KPPN dapat dilakukan dengan dua cara yaitu:

1. Melalui Uang Persediaan (UP) sebagai uang muka kerja yang dibayarkan kepada Bendahara Pengeluaran (BP) pada instansi/lembaga yang menguasai anggran ybs.

2. Langsung (LS) kepada pihak ketiga yang berhak atas tagihan kepada Negara.

Pada dasarnya semua tagihan kepada Negara dibayarkan secara langsung kepada orang atau pihak ketiga yang berhak atas tagihan tersebut.

${ }^{16}$ Lihat Penjelasan Pasal 23 UUD 1945.

${ }^{17}$ Lihat Peraturan Menteri Keuangan Republik Indonesia Nomor 134/PMK.06/2005 Tentang Pedoman Pembayaran Dalam Pelaksanaan Anggaran Pendapatan dan Belanja Negara juncto Peraturan Direktur Jenderal Perbendaharaan Nomor Per-66/PB/2005 Tentang Mekanisme Pelaksanaan Pembayaran Atas Beban Anggaran Pendapatan dan Belanja Negara. 
Dengan cara menkredit kepada rekening yang bersangkutan. Hanya untuk hal-hal kecil yang tidak bisa dibayarkan kepada yang berhak yang dapat dibayarkan melalui Bendaharawan pengeluaran melalui mekanisme uang persediaan. Misalnya untuk beli bensin operasional kendaraan, bayar rekening listrik, air dan sebagainya, serta untuk operassioanl keperluan kantor sehari-hari yang kecil-kecil yang jumlahnya tidak boleh melebihi Rp. 10.000.000,- (sepuluh juta), atau karena yang berhak tidak mempunyai nomor rekening pada suatu bank.

Pembayaran dilakukan dengan menggunakan Surat Perintah Pencairan Dana (SP2D) dengan mendebet rekening Kas Umum Negara pada bank operasional KPPN. SP2D diterbitkan atas dasar Surat Perintah Membayar (SPM) dari masing-masing Instansi/Kantor/Satker yang bersangkutan. SPM diterbitkan atas dasar adanya Surat Permintaan Pembayaran (SPP). SPM hanya dapat diterbitkan jika bukti-bukti tagihan kepada Negara sebagai lampiran SPP telah memenuhi syarat. Dengan kata lain tidak mungkin dan tidak boleh diterbitkan SPM jika lampiran SPP yang menjadi dasar penerbitannya tidak lengkap dan tidak memenuhi syarat atau tidak benar menurut tatacara pembuatan bukti-bukti tagihan kepada Negara. Bukti yang paling autentik pengeluaran Negara adalah kuitansi yang ditandatangani oleh yang berhak menerima tagihan dari Negara sesuai dengan peruntukannya.

Berdasarkan Peraturan Dirjen Perbendaharaan Nomor Per-66/PB/2005 (Per- 66), Pasal 4 bukti tagihan kepada Negara sebagai lampiran SPP diatur sebagai berikut:

1. SPP-UP (Uang Persediaan)

Surat Pernyataan dari KPA atau pejabat yang ditunjuk, yang menyatakan bahwa UP tersebut tidak untuk membiayai pengeluaran-pengeluaran yang menurut ketentuan harus dengan cara pembayaran langsung (LS).

2. SPP-TUP (Tambahan Uang Persediaan)

a. Rincian Rencana Penggunaan Dana Tambahan Uang Persediaan dari KPA atau pejabat yang ditunjuk.

b. Surat Pernyataan dari KPA atau pejabat yang ditunjuk bahwa:

(1) Dana Tambahan UP tersebut akan digunakan untuk keperluan mendesak dan akan habis digunakan dalam waktu satu bulan terhitung sejak tanggal diterbitkannya SP2D.

(2) Apabila terdapat sisa dana TUP harus disetor ke Rekening Kas Negara.

(3) Tidak untuk membiayai pengeluaran yang seharusnya dibayarkan secara langsung. 
c. Rekening Koran yang menunjukan saldo terakhir.

3. SPP-GUP (Penggantian Uang Persediaan)

a. Kuitansi/tanda bukti pembayaran.

b. Surat Pernyataan Tanggungjawab Belanja (SPTB).

c. Surat Setoran Pajak (SSP) yang telah dilegalisir oleh Kuasa Pengguna Anggaran atau Pejabat yang ditunjuk.

4. SPP-LS untuk pembayaran gaji, lembur dan honor/vakasi.

a. Pembayaran Gaji Induk/Gaji Susulan/Kekurangan Gaji/Gaji Terusan/Uang Duka Wafat/Tewas, dilengkapi dengan daftar gaji induk/Gaji Susulan/Kekurangan Gaji/Uang Duka Wafat/Tewas, SK CPNS, SK PNS, SK Kenaikan Pangkat, SK Jabatan, Kenaikan Gaji Berkala, Surat Pernyataan Pelantikan, Surat Pernyataan Masih Menduduki Jabatan, Surat Pernyataan Melaksanakan Tugas, Daftar Keluarga (KP 4), Foto Kopi Surat Nikah, Foto Kopi Akte Kelahiran, SKPP (Surat Keterangan Penghentian Pembayaran) Daftar Potongan. Sewa Rumah Dinas, Surat Keterangan Masih sekolah/Kuliah, Surat Pindah, Surat Kematian, SPP PPh Pasal 21. Kelengkapan tersebut digunakan sesuai peruntukannya.

b. Pembayaran lembur dilengkapi dengan daftar pembayaran perhitungan pembayaran lembur yang ditandatangani oleh Kuasa Pengguna Anggaran/Pejabat yang ditunjuk dan Bendahara Pengeluaran Satker/SKS yang bersangkutan, surat perintah kerja lembur, daftar hadir kerja, daftar hadir lembur dan SSP PPh Pasl 21.

c. Pembayaran Honor/Vakasi dilengkapi dengan surat keputusan tentang pemberian honor vakasi, daftar pembayaran perhitungan honor/vakasi yang ditanda tangani oleh kuasa $\mathrm{PA} /$ Pejabat yang ditunjuk dan BP yang bersangkutan, dan SSP $\mathrm{PPh}$ Pasal 21.

5. SPP-LS Non Belanja Pegawai.

a. Pembayaran pengadaan barang dan jasa:

(1) Kontrak/SPK yang mencantumkan nomor rekening rekanan;

(2) Surat Pernyataan Kuasa PA mengenai penetapan rekanan;

(3) Berita Acara Penyelesaian Pekerjaan;

(4) Berita Acara Serah Terima Pekerjaan;

(5) Berita Acara Pembayaran;

(6) Kuitansi yang disetujui oleh kuasa PA atau pejabat yang ditunjuk; 
(7) Faktur Pajak beserta SSP yang telah ditandatangani wajib pajak;

(8) Jaminan bank atau yang dipersamakan yang dikeluarkan oleh bank atau lembaga keuangan non bank;

(9) Dokumen lain yang dipersyaratkan untuk kontrak-kontrak yang dananya sebagian atau seluruhnya bersumber dari pinjaman/hibah luar negeri;

(10) Ringkasan kontrak.

b. Pembayaran biaya langganan daya dan jasa (listrik, telepon dan air):

(1) Bukti tagihan daya dan jasa;

(2) Nomor rekening pihak ketiga (PT PLN, PT Telkom, PDAM, dll)

Itulah lampiran SPP sebagai bukti pengeluaran yang harus dilengkapi agar dapat diterbitkan SPM, untuk kemudian dilakukan pembayaran sesuai peruntukannya.

Sedang khusus untuk SPP Pengadaan Tanah mengingat tingkat kerawanan dan kerumitannya yang tinggi maka diatur secara khusus melalui mekanisme pembayaran langsung (LS) dengan melampirkan bukti-bukti sebagai berikut:

1. Persetujuan Panitia Pengadaan Tanah untuk tanah yang luasnya lebih dari 1 (satu) hektar di kabupaten/kota;

2. Foto copy bukti kepemilikan tanah;

3. Kuitansi yang ditandatangani oleh yang berhak;

4. Bukti lunas PBB (Pajak Bumi dan Bangunan) tahun transaksi;

5. Surat Persetujuan harga dari instansi yang memerlukan tanah dan pemegang hak atas tanah;

6. Pernyataan dari penjual bahwa tanah tersebut tidak dalam sengketa dan tidak sedang dalam agunan;

7. Pelepasan/penyerahan hak atas tanah/akta jual beli dihadapan PPAT;

8. SSP PPh final atas pelepasan hak;

9. Surat pelepasan hak adat untuk tanah ulayat bila diperlukan.

Jika diuraikan lebih jauh kesembilan persyaratan tersebut diatas dapat dimaknai bahwa pembayaran ganti rugi dalam pengadaan tanah bagi pembangunan untuk kepentingan umum dilakukan oleh KPPN selaku Kuasa BUN langsung kepada pemegang hak atas tanah atas sepengetahuan panitia pengadaan tanah dengan cara mengkredit rekening pemegang hak atas tanah 
pada bank yang ditunjuk (bank pemegang hak atas tanah) ${ }^{18}$. Tanah yang dibebaskan jelas statusnya, yakni tidak sedang dalam sengketa, tidak sedang bermasalah, dan tidak dalam status sedang dijadikan agunan atau jaminan atas suatu pinjaman/ utang piutang. Pihak yang menerima pembayaran ganti rugi dijamin keabsahannya benar-benar pemegang hak atas tanah yang akan dibebaskan untuk kepentingan instansi yang memerlukan. Ini dibuktikan oleh sertifikat atas tanah tersebut. . Kewajiban-kewajiban atas tanah juga telah dilunasi, seperti pajak, PBB dan sabagainya. Dengan kata lain Menteri Keuangan selaku Bendahara Umum Negara (KPPN) hanya akan melakukan pembayaran ganti rugi atas pengadaan tanah, jika tanah tersebut dalam status clearance. Oleh karenanya tidak mungkin terjadi penitipan uang ganti rugi ke pengadilan negeri, karena memang uang tersebut tidak berada ditangan BP dari instansi yang memerlukan tanah ataupun ditangan panitia pembebasan tanah.

Jika benar-benar dalam keadaan terpaksa yang tidak mungkin bisa dilaksanakan pembayaran dengan cara langsung (LS), misalnya karena pemegang hak atas tanah yang akan dibebaskan berada jauh di desa, buta huruf, dan tidak mempunyai rekening disalah satu bank, atau pemilik tanah tersebut banyak, atau tanah ulayat maka dapat dilakukan pembayaran secara tunai dengan sistem UP melalui BP pada instansi yang memerlukan tanah, tetapi status tanah dan kepemilikannya tetap harus clearance.

Namun demikian Bendaharawan tidak dapat menerbitkan SPM langsung, atau KPPN tidak diperkenankan melakukan pembayaran secara otomatis hanya karena alasan tersebut saja. Tetapi harus mendapat ijin dispensasi terlebih dahulu dari Kantor Pusat Direktorat Jenderal Perbendaharaan atau Kantor wilayah Ditjen Perbendahaaraan setempat. Ijin dispensasi akan diberikan jika di lampiri bukti atau pernyataan dari kedua belah pihak (Pemegang hak atas tanah dan instansi yang membutuhkan lahan untuk kepentingan pembangunan) bahwa telah tercapai kesepakatan besaran harga ganti rugi atas tanah yang akan dilakukan pelepasan hak, disamping terpenuhinya sembilan syarat tersebut diatas. Dengan kata lain pembayaran pengadaan tanah dengan mekanisme UP dilakukan semata-mata hanya untuk mengatasi kesulitan pemegang hak atas tanah menerima uang pembayaran ganti rugi. Satu dan lain hal dikaitkan dengan mekanisme pembayaran dengan sistim giralisasi. Bendaharawan harus segera melakukan pembayaran

${ }^{18}$ Mekanisme pembayaran atau pengeluaran belanja Negara oleh KPPN tidak pernah dilakukan secara tunai atau cash, tetapi dengan sistim giralisasi melalui pemindahbukuan dari rekening Kas Umum Negara pada Bank Operasional mitra kerjanya ke rekening pihak ketiga yang berhak. Lihat Peraturan Menteri Keuangan No. 134/PMK.06/2005 Pasal 1 ayat 4. 
kepada pemegang hak atas tanah paling lambat satu bulan berikutnya. Sebab setiap uang yang dibayarkan melalui mekanisme UP ke Bendahara harus dipertanggungjawabkan penggunaannya paling lambat satu bulan sejak diterbitkannya SP2D. Apabila Bndaharawan tidak bisa mempertanggungjawabkan, maka kepadanya tidak akan diberikan lagi penggantian UP untuk dana opersional sehari-hari perkantoran.

Dengan demikian lembaga konsinyasi tidak dikenal dan tidak diperlukan dalam pengelolaan Belanja Negara. Setiap penerimaan Negara harus masuk ke kas Negara, dan setiap pengeluaran Negara harus dapat dipertangungjawabkan atas bukti yang sah dan benar. Bukti titipan uang kepada pengadilan bukanlah bukti pengeluaran yang benar. ${ }^{19}$ Karena tidak ditanda tangani oleh orang yang berhak menerima pembayaran sesuai peruntukan yaitu ganti rugi pengadaan tanah.

Penggunaan terhadap lembaga konsinyasi dalam pengadaan tanah jika masyarakat tetap menolak besarnya ganti kerugian adalah suatu kesalahan besar. Karena perbuatan hukum pengadaan tanah merupakan perbuatan hukum antara pemerintah dengan pemegang hak atas tanah untuk memperoleh tanah, dan bukannya perbuatan hukum dalam lapangan keperdataan atau bisnis seperti hubungan utang piutang dalam pasal 404 KUH Perdata dimana pelakunya adalah orang atau kelompok orang yang sama-sama sebagai subjek hukum privat.

Sesuai dengan pedoman dan mekanisme pelaksanaan pembayaran atas beban APBN, maka bila tidak tercapai kata sepakat mengenai besarnya ganti kerugian, maka tidak akan terjadi pengeluaran Negara. Pengeluaran Negara hanya boleh dilakukan untuk hal-hal yang sudah pasti.

\section{Kesimpulan}

1. Lembaga Konsinyasi tidak diperlukan dan tidak dikenal dalam pengurusan pengeluaran (belanja) Negara, karena pengeluaran Negara harus dilakukan atas bukti yang sah dan benar serta jelas peruntukannya. Dalam mekanisme pelaksanaan pembayaran atas beban APBN khususnya pembayaran ganti rugi dalam pengadaan tanah bagi pelaksanaan pembangunan untuk kepentingan umum, pembayaran dilakukan langsung (LS) kepada pemegang hak atas tanah setelah status tanah clearance. Pembayaran bukan kepada

${ }^{19}$ Lihat Keppres No. 42 Tahun 2002 Tentang Pedoman Pelaksanaan Anggaran Pendapatan dan Belanja Negara berikut perubahan-perubahannya, terakhir Keppres No. 72 Tahun 2004. 
Bendaharawan instansi yang memerlukan tanah. Jadi tidak mungkin ada uang titipan ke Pengadilan. Jika pembayaran ganti rugi terpaksa dilakukan melalui Bendaharawan, itu semata-mata hanya untuk mengatasi kesulitan pemegang hak atas tanah menerima pembayaran ganti rugi sehubungan sistim giralisasi.

2. Setiap penerimaan Negara harus masuk ke kas Negara, dan setiap belanja Negara harus dipertanggungjawabkan atas dasar bukti pengeluaran yang sah dan benar (kuitansi) yang ditanda tangani oleh pihak yang berhak menerima pembayaran dari negara. Kuitansi (Bukti penitipan) uang ke Pengadilan bukanlah bukti pengeluaran yang benar, dan oleh karena itu bertentangan dengan mekanisme pelaksanaan pembayaran atas beban APBN. Semoga hal ini menjadi pemikiran kita bersama untuk meluruskannya dimasa yang akan datang. 


\section{Daftar Pustaka}

\section{Buku-buku}

Ibrahim. Prospek Badan Usaha Milik Negara dan Kepentingan Umum, Bandung: Citra Aditya Bakti, 1997.

Kusumaatmadja, Mochtar. Konsep-Konsep Hukum Dalam Pembangunan, Bandung: Alumni, 2002.

Parlindungan, A.P. Berbagai Aspek Pelaksanaan UUPA, Bandung: Alumni, 1978.

Ruchiyat, Eddy. Politik Pertanahan sampai Orde Reformasi, Bandung: Alumni, 2004.

Soeria Atmadja, Arifin, P. Mekanisme Pertanggungjawaban Keuangan Negara, Suatu Tinjauan Yuridis, Jakarta: Gramedia, 1986.

Sumardjono, Maria S.W., Kebijakan Pertanahan antara Regulasi dan Implementasi, Jakarta: Penerbit Buku Kompas, 2005.

\section{Makalah, Majalah, Seminar}

Hasan, Djuhaendah. Aspek Hukum Ekonomi dalam Pengadaan Tanah Untuk Kepentingan Pembangunan, Makalah yang disampaikan pada seminar Nasional Pengadaan Tanah Untuk Kepentingan Pembangunan, yang diselenggarakan oleh Fak. Hukum Unpad (Jakarta 14 September 2006): hal. 1.

Hermayulis, 2000, Aspek-Aspek Hukum Hak Pakai Atas Tanah Negara sebagai Objek Jaminan, Hukum Bisnis, Volume 10 Tahun ........, hal. 49.

Soeria Atmadja, Arifin, P. "Segi Hukum Pertanggungjawaban Keuangan Negara", Majalah Hukum dan Pembangunan UI, No. 3 tahun ke VIII, 1978.

Sumardjono, Maria S.W. Penerapan Prinsip Penghormatan Hak Atas Tanah dalam Pengadaan Tanah Untuk Kepentingan Pembangunan, Makalah yang disampaikan pada Seminar Nasional Pengadaan Tanah Untuk Kepentingan Pembangunan, yang diselenggarakan oleh Fak. Hukum Unpad (Jakarta 14 September 2006), hal. 5. 


\section{Peraturan Perundang-Undangan}

Indonesia, Undang-Undang Dasar 1945, LN. N0. 75 Tahun 1959.

. Undang-Undang Tentang Keuangan Negara, UU No. 17 Tahun 2003, LN No. 47 Tahun 2003, TLN No. 4286.

. Undang-Undang Tentang Perbendaharaan Negara, UU No. 1 Tahun 2004, LN No. 5 Tahun 2004, TLN No. 4355.

Peraturan Pemerintah Tentang Penyusunan Rencana Kerja Anggaran Kementerian/Lembaga (RKA/KL) Tahun 2006, PP. No. 1 Tahun 2006.

Keputusan Presiden Tentang Pedoman Pelaksanaan Anggaran Pendapatan Dan Belanja Negara, Keppres No. 42 Tahun 2002.

Keputusan Presiden Tentang Perubahan Atas Keppres Nomor 42 Tahun 2002 Tentang Pedoman Pelaksanaan Anggaran Pendapatan dan Belanja Negara, Keppres No. 72 Tahun 2004.

Departemen Keuangan Republik Indonesia, Peraturan Menteri Keuangan Tentang Pedoman Pembayaran Dalam Pelaksanaan Anggaran Pendapatan dan Belanja Negara, PMK No. 134/PMK.06/2005.

Peraturan Direktur Jenderal Perbendaharaan Tentang Mekanisme Pelaksanaan Pembayaran Atas Beban Anggran Pendapatan Dan Belanja Negara, Perdirjen PBN No. Per-66/PB/2005. 